\title{
PENERAPAN METODE MULTIVARIATE ADAPTIVE REGRESSION SPLINE (MARS) UNTUK MENGIDENTIFIKASI KOMPONEN YANG BERPENGARUH TERHADAP PERINGKAT AKREDITASI SEKOLAH (Kasus SMA/MA Di Propinsi Sumatera Barat)
}

\author{
AZZIKRA FEBRIYANTI, HAZMIRA YOZZA, IZZATI RAHMI HG \\ Program Studi Matematika, \\ Fakultas Matematika dan Ilmu Pengetahuan Alam, Universitas Andalas, \\ Kampus UNAND Limau Manis Padang, Indonesia, \\ fazzikra@yahoo.co.id,hyozza@gmail.com, izzatirahmihg@yahoo.com
}

\begin{abstract}
Abstrak. Peringkat akreditasi sekolah SMA/ MA dapat diduga berdasarkan delapan komponen yang telah ditetapkan oleh pemerintah dalam Peraturan Menteri Pendidikan Nasional Nomor 52 Tahun 2008 yaitu komponen standar isi, komponen standar proses, komponen standar kompetensi lulusan, komponen standar pendidik dan tenaga kependidikan, komponen standar sarana dan prasarana, komponen standar pengelolaan, komponen standar pembiayaan, dan komponen standar penilaian. Penelitian ini bertujuan untuk mengindentifikasi komponen apa saja yang mempengaruhi pengelompokan akreditasi. Peringkat akreditasi yang didapatkan oleh sekolah dapat dikelompokan menjadi dua kelompok dengan kelompok 1 adalah sekolah yang terakreditasi A atau B, dan kelompok 2 adalah sekolah yang terakreditasi $\mathrm{C}$ atau tidak terakreditasi. Pendugaan terhadap kelompok sekolah dapat diduga dengan menggunakan pendekatan Multivariate Adaptive Regression Spline (MARS). Data yang digunakan adalah data yang dikeluarkan oleh Badan Akreditasi Nasional Sekolah Menengah (BAN-SM) yang memuat data akreditasi SMA/MA se-Sumatera Barat. Hasil pendugaan pengelompokan sekolah dengan metode MARS menghasilkan beberapa variabel yang berpengaruh secara signifikan, antara lain : komponen standar sarana dan prasarana $\left(X_{5}\right)$, komponen standar kompetensi lulusan $\left(X_{3}\right)$, komponen standar penilaian $\left(X_{8}\right)$, komponen standar isi $\left(X_{1}\right)$, komponen standar pembiyaan $\left(X_{7}\right)$, komponen standar proses $\left(X_{2}\right)$, dan komponen standar pengelolaan $\left(X_{6}\right)$ dengan tingkat kepentingan berturut-turut 100\%, 83.93\%, 56.27\%, 54.27\%, 45.86\%, $23.3 \%, 22.67 \%$.
\end{abstract}

Kata Kunci: Komponen Akreditasi, Multivariate Adaptive Regression Spline (MARS)

\section{Pendahuluan}

Dunia pendidikan merupakan bidang yang selalu mendapat perhatian khusus dari berbagai pihak, mulai dari masyarakat sebagai yang menerima jasa pendidikan sampai ke Kementerian Pendidikan Nasional sebagai wadah yang menaungi seluruh tingkat pendidikan yang ada di Indonesia. Perhatian terhadap dunia pendidikan melahirkan penilaian-penilaian yang pada akhirnya diharapkan dapat memberikan masukan bagi perkembangan pendidikan di masa-masa yang akan datang. Untuk menyamakan penilaian berbagai pihak terhadap mutu sekolah sebagai sarana pen- 
didikan, maka pemerintah melalui Badan Akreditasi Nasional (BAN) memberikan nilai akrediatasi yang merupakan hasil penilaian secara komprehensif terhadap berbagai indikator mutu di sekolah tersebut.

Banyak pihak yang mempunyai pandangan bahwa sekolah yang bermutu adalah sekolah yang terakreditasi A atau B. Lain halnya bila sekolah memiliki akreditasi C.Meskipun sekolah ini sudah memenuhi standar pendidikan tetapi sekolah yang berakreditasi $\mathrm{C}$ masih kurang mendapat pengakuan di masyarakat sehingga terkadang disamakan dengan sekolah yang belum terakreditasi. Hal ini terjadi diakibatkan masyarakat menganggap bahwa hal yang paling menentukan peringkat akreditasi sekolah adalah kualitas lulusan yang biasanya diukur dengan nilai rata-rata Ujian Nasional dan persentase kelulusan di sekolah tersebut sehingga mengabaikan faktor-faktor lain. Berdasarkan Peraturan Menteri Pendidikan Nasional Nomor 52 Tahun 2008 disebutkan bahwa terdapat delapan komponen penilaian dalam menentukan akreditasi SMA/MA yaitu, komponen standar isi, komponen standar proses, komponen standar kompetensi lulusan, komponen standar pendidik dan tenaga kependidikan, komponen standar sarana dan prasarana, komponen standar pengelolaan, komponen standar pembiayaan, dan komponen standar penilaian.

Hal menarik yang ingin diketahui adalah komponen mana yang paling membedakan kelompok-kelompok sekolah berdasarkan akreditasi. Diharapkan hal ini dapat membantu sekolah-sekolah yang berada dalam proses pengusulan akreditasi, untuk dapat menyusun prioritas dalam penilaian kompononen pengakreditasian. Untuk mencapai tujuan tersebut dapat digunakan beberapa metode dalam analisis regresi. Analisis regresi memiliki beberapa pendekatan dalam menduga sebuah hubungan antara variabel, yaitu metode parametrik dan metode non parametrik. MARS (Multivariate Adaptive Regression Splines) merupakan pendekatan regresi nonparametrik yang menghasilkan pemodelan regresi yang fleksibel untuk data dengan variabel prediktor $3 \leq k \leq 20$ dan ukuran contoh $50 \leq \mathrm{n} \leq 1000$. Model MARS merupakan perluasan hasil kali fungsi basis spline, dimana jumlah fungsi basis beserta parameter parameternya (derajat hasil kali, lokasi knot) ditentukan oleh data dengan menggunakan algoritma recursive partitioning yang dimodifikasi.

\section{Multivariate Adptive Regression Spline (MARS)}

Pada tahun 1990, Jerome H. Friedman memperkenalkan metode MARS sebagai suatu metode baru yang mengotomatiskan pembangunan model-model prediktif akurat untuk variabel-variabel respon kontinu dan biner. Model MARS difokuskan untuk mengatasi permasalahan dimensi yang tinggi dan diskontiouitas pada data. MARS merupakan pengembangan dari pendekatan Recursive Partition Regression (RPR) yang menghasilkan model yang tidak kontinu pada knot[4].

Beberapa hal yang perlu diperhatikan dalam membangun model MARS yaitu:

a. Knot, merupakan nilai variabel prediktor ketika slope suatu garis regresi mengalami perubahan yang dapat didefinisikan sebagai akhir dari satu segmen sekaligus merupakan awal dari segmen yang lain. Di setiap titik knot, diharapkan adanya kontinuitas dari fungsi basis antar satu region dengan region lain- 
nya. Minimum observasi antara knot (MO) adalah 0, 1, 2, dan 3 observasi.

b. Fungsi basis $(B F)$ yaitu selang antar knot yang berurutan. Pada umumnya fungsi basis yang dipilih berbentuk polinomial dengan turunan yang kontinu pada setiap titik knot. Maksimum fungsi basis yang diijinkan adalah 2-4 kali jumlah variabel prediktornya.

c. Interaction (interaksi) yaitu hasil perkalian silang antar variabel yang saling berkorelasi. Jumlah maksimum interaksi (MI) yang diperbolehkan adalah 1, 2, atau 3. Jika $M I>3$ akan dihasilkan model yang semakin kompleks dan model akan sulit untuk diinterpretasi.

Model MARS adalah sebagai berikut :

$$
f(x)=a_{0}+\sum_{m=1}^{M} a_{m} \prod_{k=1}^{k_{m}}\left(S_{k m}\left(X_{V(k, m)}-t_{k m}\right)\right)+
$$

dengan

$a_{0} \quad:$ konstanta regresi dari fungsi basis

$a_{m} \quad$ : koefisien dari fungsi basis ke- $m, m=1, \cdots, M$

$M \quad$ : maksimum fungsi basis (nonconstant fungsi basis)

km : derajat interaksi

$S_{k m}:\left\{\begin{array}{l}+1, \text { jika knot terletak dikanan subregion } \\ -1, \text { jika knot terletak dikiri subregion }\end{array}\right.$

$X_{v(k, m)}$ : variabel prediktor

$t_{k m} \quad$ : nilai knots dari variabel prediktor $X_{v}(k, m)$.

Koefisien $\left\{a_{m}\right\}_{m=1}^{M}$ ditentukan dengan metode kuadrat terkecil. Model MARS juga dapat ditulis dalam bentuk sebagai berikut :

$$
\hat{f}_{x}=\alpha_{0}+\alpha_{1} B_{1}+\alpha_{2} B_{2}+\alpha_{3} B_{3}+\cdots+\alpha_{M} B_{M}
$$

Pemilihan knots pada MARS dilakukan dalam dua tahap yaitu tahap forward dan tahap backward. Forward dilakukan untuk mendapatkan fungsi dengan jumlah basis maksimum dan nantinya akan dipilih fungsi basis dengan Metode kuadrat terkecil. Pada tahap backward akan dipilih satu fungsi basis dan mengeluarkan basis tersebut jika kontribusi terhadap model kecil. Proses backward akan dilanjutkan hingga tidak ada fungsi basis yang dapat dikeluarkan. Ukuran kontirbusi pada tahap backward ditentukan berdasarkan kriteria Generalized Cross Validation (GCV) yang diperkenalkan oleh Wahba pada tahun 1979. Fungsi GCV didefinisikan sebagai berikut :

$$
G C V(M)=\frac{1 / N \sum_{i=1}^{N}\left[y_{i}-\hat{f}_{M}\left(x_{i}\right)\right]^{2}}{[1-(C(M)) / N]^{2}}
$$

dengan

$M \quad$ : jumlah fungsi basis

$x_{i} \quad$ : variabel prediktor

$y_{i} \quad$ : variabel respon

$N \quad$ : banyaknya pengamatan 
$C(M):$ Trace $\left[\boldsymbol{B}\left(\boldsymbol{B}^{T} \boldsymbol{B}\right)^{-1} \boldsymbol{B}^{T}\right]+1$

Pada model MARS dilakukan uji signifikansi fungsi basis yang meliputi uji bersamaan dan uji individu. Uji signifikansi yang dilakukan secara bersamaan/serentak terhadap fungsi basis-fungsi basis yang terdapat dalam model MARS ini bertujuan untuk mengetahui apakah secara umum model MARS terpilih merupakan model yang sesuai dan menunjukkan hubungan yang tepat antara variabel prediktor dengan variabel respon. Hipotesis yang digunakan adalah:

$H_{0}: \alpha_{1}=\alpha_{2}=\cdots=\alpha_{m}=0$

$H_{1}:$ ada $\alpha_{j} \neq 0, j=1,2, \cdots, m$

Hipotesis nol $H_{0}$ akan ditolak jika $F_{\text {hitung }}>F_{\alpha\left(v_{1}, v_{2}\right)}$ artinya tidak terdapat pengaruh fungsi basis terhadap model. Nilai $F_{\alpha\left(v_{1}, v_{2}\right)}$ diperoleh dari tingkat signifikansi $\alpha$ serta $v_{1}=k$ dan $v_{2}=n-k-1$ dengan $n$ adalah banyaknya sampel dan $k$ adalah banyaknya fungsi basis yang berkontribusi terhadap model. Nilai $F_{\text {hitung }}$ diperoleh dari perhitungan berikut

$$
F_{\text {hitung }}=\frac{\sum_{i=1}^{n}\left(\hat{y}_{l}-\bar{y}\right)^{2} / k}{\sum_{i=1}^{n}\left(y_{i}-\hat{y}_{l}\right)^{2} / n-k-1} .
$$

Kemudian akan dilakukan pengujian untuk masing - masing fungsi basis yang bertujuan untuk mengetahui apakah fungsi basis yang terbentuk mempunyai pengaruh signifikan terhadap model, selain itu ingin diketahui pula apakah model yang memuat parameter tersebut telah mampu menggambarkan keadaan data yang sebenarnya. Hipotesisnya adalah sebagai berikut :

$H_{0}: \alpha_{j}=0$

$H_{1}: \alpha_{j} \neq 0, j=1,2, \cdots, m$

Hipotesis nol $H_{0}$ akan ditolak jika $t_{\text {hitung }}>t_{\left(\frac{\alpha}{2}, v_{2}\right)}$ artinya tidak terdapat pengaruh variabel prediktor terhadap variabel respon pada fungsi basis ke- $j$ di dalam model. Nilai $t_{\left(\frac{\alpha}{2}, v_{2}\right)}$ diperoleh dengan derajat bebas $v_{2}=k$ dan tingkat signifikansi dan nilai $t_{\text {hitung }}$ diperoleh dari

$$
t_{\text {hitung }}=\frac{\alpha_{j}}{s_{a_{j}}}
$$

dengan $s_{\alpha_{j}}$ merupakan standar error $\alpha_{j}$ yang diperoleh dari

$$
s_{\alpha_{j}}=\sqrt{\left(\frac{\sum_{i=1}^{n}\left(y_{i}-\hat{y}_{l}\right)^{2}}{n-k-1}\right) C_{j j}} .
$$

\section{Klasifikasi Pada $M A R S$}

Pada model MARS, masalah klasifikasi didasarkan pada pendekatan analisis regresi. Jika variabel respon terdiri dari dua nilai, maka dikatakan sebagai regresi dengan respon biner [3] sehingga dapat digunakan model probabilitas dengan persamaan berikut :

$$
P(Y=1 \mid X=\mathbf{x})=\pi(\mathbf{x})=\frac{e^{f(x)}}{1+e^{f(\mathbf{x})}}
$$




$$
P(Y=0 \mid X=x)=\left(1-\pi(\mathbf{x})=\frac{1}{1+e^{f(\mathbf{x})}}\right.
$$

Variabel respon $Y$ merupakan variabel respon biner (0dan1) dengan $p$ banyaknya variabel prediktor $\mathbf{x}=\left(x_{1}, x_{2}, x_{p}\right)$, sehingga model MARS untuk klasifikasi [3] dapat dinyatakan sebagai:

$$
\operatorname{logit} \pi(\mathbf{x})=\ln \left(\frac{\pi(\mathbf{x})}{1-\pi(\mathbf{x})}\right)=\alpha_{0}+\sum_{m=1}^{M} \alpha_{m} \Pi_{k=1}^{K_{m}}\left[s_{k m} \cdot\left(x_{v(k, m)}-t_{k m}\right)\right]
$$

Untuk menghitung ketepatan klasifikasi pada hasil pengelompokan digunakan apparent error rate (APER). Nilai APER menyatakan reresentasi proporsi sampel yang salah diklasifikasikan.Dalam penelitian kali ini digunakan respon biner sehingga penentuan kesalahan klasifikasi dapat dihitung dari tabel Klasifikasi berikut :

\begin{tabular}{|c|c|c|}
\hline \multirow{2}{*}{$\begin{array}{c}\text { Hasil } \\
\text { Observasi }\end{array}$} & \multicolumn{2}{|c|}{$\begin{array}{c}\text { Hasil Prediksi } \\
\text { (predicted class) }\end{array}$} \\
\cline { 2 - 3 } (actual class) & Kelompok 1 & Kelompok 2 \\
\hline Kelompok 1 & $\mathrm{n}_{11}$ & $\mathrm{n}_{12}$ \\
\hline Kelompok 2 & $\mathrm{n}_{21}$ & $\mathrm{n}_{22}$ \\
\hline
\end{tabular}

Gambar 1. Tabel Klasifikasi Model MARS

- $n_{11}=$ Jumlah observasi kelompok 1 yang tepat diklasifikasikan sebagai kelompok 1 .

- $n_{12}=$ Jumlah observasi kelompok 1 yang salah diklasifikasikan sebagai kelompok 2 .

- $n_{21}=$ Jumlah observasi kelompok 2 yang salah diklasifikasikan sebagai kelompok 1

- $n_{22}=$ Jumlah observasi kelompok 2 yang tepat diklasifikasikan sebagai kelompok 2 .

Nilai APER dihitung sebagai berikut :

$$
A P E R(\%)=\frac{n_{11}+n_{21}}{n_{11}+n_{12}+n_{21}+n_{22}} \times 100 \%
$$

Sebagai statistik uji untuk mengetahui sejauh mana kelompok-kelompok ini dapat dipisahkan dengan menggunakan variabel yang ada mempunyai kestabilan dalam ketepatan klasifikasi digunakan Press's Q, yang diformulasikan sebagai berikut :

$$
\operatorname{Press}^{\prime} s Q=\frac{[N-(n K)]^{2}}{N(K-1)}
$$

- $\mathrm{N}=$ jumlah total sampel

- $\mathrm{n}=$ jumlah individu yang tepat diklasifikasikan

- $\mathrm{K}=$ jumlah kelompok 
Jika nilai dari Press's Q ini melebihi nilai kritis (tabel $\chi$ kuadrat dengan derajat bebas 1), maka klasifikasi dapat dianggap sudah stabil dan konsisten secara statistik.

\section{Metode Penelitian}

Data yang digunakan dalam penelitian ini adalah data peringkat akreditasi serta hasil penilaian kedelapan komponen akreditasi dari 365 sekolah menengah atas sederajat (SMA/MA) yang ada di propinsi Sumatera Barat. Data ini diperoleh melalui situs Badan Akreditasi Sekolah Menengah (BAN-SM), http//:www.ban-sm.or.id.

Variabel respons pada penelitian ini adalah peringkat akreditasi sekolah, dimana pada penelitian kali ini dikelompokan ke dalam dua kategori dengan skala nominal, yaitu:

$Y=0$ : Kelompok sekolah yang mendapatkan akreditasi A atau B. Sekolahsekolah pada kelompok ini diberikan nilai $Y=0$.

$Y=1$ : Kelompok sekolah yang mendapatkan akreditasi $\mathrm{C}$ atau tidak terakreditasi. Sekolah-sekolah pada kelompok ini diberikan nilai $Y=1$.

Variabel prediktor pada penelitian ini adalah nilai delapan komponen penilaian akreditasi sekolah menengah terdiri dari :

$X_{1}$ : Komponen standar isi.

$X_{2}$ : Komponen standar proses.

$X_{3}$ : Komponen standar lulusan.

$X_{4}$ : Komponen standar pendidik dan tenaga didik.

$X_{5}$ : Komponen standar sarana dan prasarana.

$X_{6}:$ Komponen standar pengelolaan.

$X_{7}$ : Komponen standar pembiayaan.

$X_{8}:$ Komponen standar penilaian.

Adapun langkah-langkah dalam penelitian ini adalah

(1) Mengkombinasikan besarnya basis function (BF), Maximum Interaction (MI) dan Minimum Observation (MO) pada data yang digunakan dengan cara:

- Menentukan kemungkinan maksimum banyaknya basis function (BF) yaitu 2-4 kali jumlah prediktor yang akan digunakan. Kemungkinan maksimum banyaknya fungsi basis pada penelitian ini adalah 16, 24 dan 32.

- Menentukan jumlah maksimum interaksi $(M I)$, yaitu 1,2 dan 3.

- Menentukan minimal jumlah pengamatan setiap knots $(M O)$, yaitu $0,1,2$ dan 3.

(2) Menetapkan model terbaik dengan didasarkan pada nilai $G C V$ minimum yang diperoleh dengan mengkombinasikan maksimum $B F, M I$, dan $M O$.

(3) Menduga koefisien model menggunakan metode kuadrat terkecil.

(4) Melakukan uji signifikansi fungsi basis model MARS. 
(5) Mengelompokkan fungsi basis berdasarkan variabel prediktor yang masuk dalam model.

(6) Menginterpretasikan tingkat kontribusi dan pengurangan $G C V$ variabel yang mempunyai kepentingan dalam pengelompokan variabel respon.

(7) Menguji keakurasian prediksi model MARS (ketepatan klasifikasi) yang terbentuk dari data dengan menggunakan APER serta menghitung kestabilan klasifikasi dengan statistik uji Press's $Q$.

\section{Analisis Dan Pembahasan}

Model terbaik pada model MARS adalah model dengan nilai $G C V$ terkecil. Berdasarkan kombinasi fungsi basis 16, 24 dan 32 dengan maksimum interaksi 1, 2 atau 3 dan minimum observasi 0, 1, 2 dan 3, GCV paling kecil diperoleh jika digunakan maksimum $B F=32, M I=3$ dan $M O=1$ yaitu $G C V=0,03454$ dan $R^{2}=00,91686$, dimana jumlah variabel prediktor yang signifikan mempengaruhi model sebanyak tujuh dari delapan variabel prediktor.

$$
\begin{aligned}
Y= & 0.0185765-0.0280002 B F_{2}+0.0358172 B F_{4}-0.0018277 B F_{5} \\
& +0.0409577 B F_{8}-0.000998631 B F_{9}-0.00106012 B F_{11}-0.00217283 B F_{12} \\
& -0.00199556 B F_{13}+0.00025573 B F_{15}+0.00014605 B F_{16}-0.000221595 B F_{17} \\
& -0.00254218 B F_{19}-0.00499549 B F_{21}+0.00648364 B F_{24}+0.00762517 B F_{25} \\
& +0.000346634 B F_{27}+2.08365 e-005 B F_{28}+0.000466602 B F_{30}+0.000169346 B F_{31}
\end{aligned}
$$

dengan

$$
\begin{array}{ll}
B F_{2}=\max \left(0,60-X_{1}\right) & B F_{17}=\max \left(0, X_{8}-81\right) B F_{14} ; \\
B F_{4}=\max \left(0,74.17-X_{5}\right) & B F_{19}=\max \left(0, X_{1}-75\right) B F_{4} \\
B F_{5}=\max \left(0, X_{8}-75\right) B F_{4} & B F_{20}=\max \left(0,75-X_{1}\right) B F_{4} \\
B F_{8}=\max \left(0,75-X_{3}\right) & B F_{21}=\max \left(0, X_{8}-85\right) B F_{20} \\
B F_{9}=\max \left(0, X_{6}-68.75\right) B F_{8} & B F_{24}=\max \left(0,70-X_{2}\right) \\
B F_{11}=\max \left(0, X_{5}-65.83\right) B F_{8} & B F_{25}=\max \left(0, X_{3}-80\right) B F_{24} \\
B F_{12}=\max \left(0,65.83-X_{5}\right) B F_{8} & B F_{27}=\max \left(0, X_{1}-78\right) B F_{12} \\
B F_{13}=\max \left(0, X_{7}-79\right) B F_{8} & B F_{28}=\max \left(0,78-X_{1}\right) B F_{12} \\
B F_{14}=\max \left(0,79-X_{7}\right) B F_{8} & B F_{30}=\max \left(0,56.67-X_{1}\right) B F_{11} \\
B F_{15}=\max \left(0, X_{1}-83.33\right) B F_{5} & B F_{31}=\max \left(0, X_{7}-85\right) B F_{11} \\
B F_{16}=\max \left(0,83.33-X_{1}\right) B F_{5} &
\end{array}
$$

Interpretasi dari koefisien-koefisien fungsi basis pada model MARS diatas adalah :

$B F_{2}=\max \left(0,60-X_{1}\right)$ dengan koefisien - 0.02800 : Setiap kenaikan BF2 sebesar satu satuan, akan mengurangi resiko sekolah masuk ke dalam kelompok 2 sebesar 0.02800. Berkurangnya resiko sekolah tidak terakreditasi ini terjadi pada sekolah yang memiliki nilai standar isi $\left(X_{1}\right)<60$.

$B F_{4}=\max \left(0,74.17-X_{5}\right)$ dengan koefisien 0.03582 : Setiap kenaikan satu satuan BF4 akan menambah resiko sekolah masuk kedalam kelompok 2 sebesar 
0.03582, hal ini terjadi pada sekolah yang memiliki nilai standar sarana dan prasarana $\left(X_{5}\right)<74,17$.

$B F_{5}=\max \left(0, X_{8}-75\right) B F_{4}$ dengan koefisien - 0.00183 : Setiap kenaikan satu satuan BF5 akan mengurangi resiko kemungkinan sekolah masuk ke dalam kelompok 2 sebesar 0.00183. Perubahan resiko ini terjadi pada sekolah yang memiliki nilai standar sarana dan prasarana $\left(X_{5}\right)<74$ dan nilai standar penilaian $\left(X_{8}\right)>75$.

Demikian seterusnya untuk interpretasi fungsi basis lainnya.

Pada model MARS yang telah diperoleh dilakukan uji signifikansi yang meliputi uji fungsi basis secara keseluruhan (secara serempak/bersama) dan uji masing-masing fungsi basis. Uji signifikansi (keberartian) yang dilakukan secara bersamaan untuk fungsi basis-fungsi basis yang terdapat pada model MARS menggunakan hipotesis berikut :

$$
\begin{aligned}
& H_{0}: \alpha_{j}=0 \\
& H_{1}: \alpha_{j} \neq 0 \\
& \quad \text { dengan } \mathrm{j}=2,4,5,8,9,11,12,13,15,16,17,18,19,21,24,25,27,28,30 \text { dan } 31
\end{aligned}
$$

Berdasarkan hasil pengolahan MARS diperoleh nilai $F_{\text {hitung }}=128,63715$. Dengan $\alpha=0,05$, nilai $v_{1}=19$ dan $v_{2}=281$ diperoleh nilai $F_{0.05(18,181)}=1,57$, karena $F_{\text {hitung }}>1,62$ maka keputusan yang diambil adalah menolak $H_{0}$ yang berarti terdapat paling tidak satu $\alpha_{j}$ yang tidak sama dengan nol atau dengan kata lain terdapat paling tidak satu fungsi basis yang memuat variabel prediktor yang berpengaruh terhadap variabel respon.

Uji yang dilakukan secara individual terhadap setiap fungsi basis menggunakan hipotesis sebgai berikut :

$$
\begin{aligned}
& H_{0}: \alpha_{j}=0 \\
& H_{1}: \alpha_{j} \neq 0 \\
& \quad \text { dengan } \mathrm{j}=2,4,5,8,9,11,12,13,15,16,17,18,19,21,24,25,27,28,30 \text { dan } 31
\end{aligned}
$$

Dalam pengujian ini digunakan $\alpha=0.05$ sehingga $t_{(}(0,025 ; 281)=1,96$.

Karena untuk semua fungsi basis diperoleh $t_{\text {hitung }}>1,96$ maka diputuskan untuk tolak $H_{0}$ yang berarti bahwa semua fungsi basis yang terpilih dalam model MARS memiliki pengaruh terhadap variabel respon.

Tingkat kepentingan variabel prediktor pada MARS ditaksir dari perubahan nilai GCV yang disebabkan oleh perpindahan variabel-variabel diatas.Urutan variabel yang berkontribusi terhadap model MARS yaitu komponen standar sarana dan prasarana, komponen standar kompetensi lulusan, komponen standar penilaian, komponen standar isi, komponen standar pembiayaan, komponen standar proses, komponen standar pengelolaan dengan tingkat kepentingan berturut-turut $100 \%, 83,93 \%, 56,27 \%, 54,27 \%, 45,86 \%, 23,35 \%, 22,67 \%$.

Model klasifikasi perlu dievaluasi untuk mengetahui seberapa besar peluang melakukan kesalahan dalam pengelompokkan sekolah berdasarkan tingkat akreditasi. Hal ini dapat dilakukan dengan menghitung nilai APER seperti pada Persamaan (3.1) yang disajikan dalam Tabel 2. Dari Tabel 2 dapat dikatakan bahwa 
tingkat kesalahan klasifikasi sebesar 5,65 \%, sehingga tingkat kesuksesan pengklasifikasian adalah sebesar 94,35\%. Hal ini menunjukkan bahwa model MARS yang dihasilkan sangat baik dalam mengelompokan sekolah berdasarkan peringkat akreditasinya.

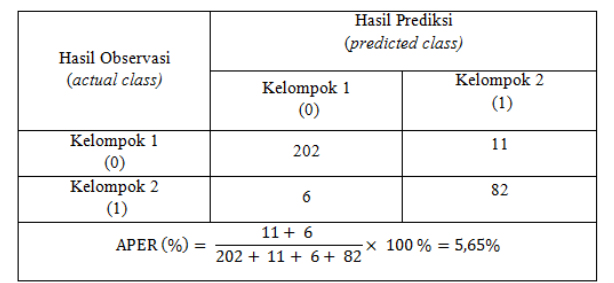

Gambar 2. Klasifikasi Model MARS

Evaluasi selanjutnya adalah menguji kestabilan pengklasifikasian model deng-an statistik uji Press'Q. Nilai statistik uji press'Q yang didapat dengan Persamaan (3.2) adalah sebesar 818,33 kemudian dibandingkan dengan nilai chi-square derajat bebas $1\left(\chi^{2}(1,0,05)=3,841\right)$. Nilai Press'Q yang didapat jauh lebih besar dari pada $\chi^{2}(1 ; 0,05)$, sehingga dapat dikatakan keakuratan pengklasifikasian sekolah berdasarkan tingkat pengelompokan akreditasi menggunakan model MARS sudah konsisten secara statistik.

\section{Kesimpulan}

Dari delapan variabel prediktor yang diteliti pada penelitian ini, terdapat tujuh variabel prediktor yang berkontribusi terhadap model MARS, yaitu komponen standar sarana dan prasarana, komponen standar kompetensi lulusan, komponen standar penilaian, komponen standar isi, komponen standar pembiayaan, komponen standar proses, komponen standar pengelolaan dengan tingkat kepentingan berturut-turut 100\%, 83.93\%, 56.27\%, 54.27\%, 45.86\%, 23.35\%, 22.67\% dan satu variabel yaitu komponen standar pendidik dan tenaga didik yang tidak berpengaruh dalam pengklasifikasian.

\section{Ucapan Terima kasih}

Penulis mengucapkan terima kasih kepada Bapak Dodi Devianto, Bapak Ahmad Iqbal Baqi dan Ibu Lyra Yulianti yang telah memberikan masukan dan saran sehingga makalah ini dapat diselesaikan dengan baik.

\section{Daftar Pustaka}

[1] Anonim. 2012. Data Akreditasi. http//:www.ban-sm.or.id. Diakses pada 29 November 2012

[2] Anonim. 2001. MARS $S^{T M}$ User Guide. Salford Systems, Inc. www.salfordsystems.com. Diakses pada 20 November 2012. 
[3] Cox, D.R. dan Snell, E.J. 1989, Analysis of Binary Data. Second Edition. Chapman and Hall, London.

[4] Friedman, J.H. 1991. Multivariate Adaptive Regression Splines. The Annals of Statistics $19: 1-67$

[5] Otok, B.W, et al. 2007. Pendekatan Bootstrap pada Klasifikasi Pemodelan Respon Ordinal. Universitas Gajah Mada, Yogyakarta.

[6] Zhang. H and B.H. Singer. 2010. Recursive partitioning and Applications 2th ed. Springer, New York. 